\begin{tabular}{|c|c|c|c|c|c|c|}
\hline 1 & DISTR & IBUTIO & SHEET & & & \\
\hline To & From & & & & Page 1 of 1 & \\
\hline Distribution & Albert & A. Krug & & & Date 22 May & 1995 \\
\hline Project Title/Work Order & & & & & EDT No. $N / A$ & \\
\hline In Situ Monitoring of Grouted & d Electroly & ytes, WHC & $-S A-2887-F$ & & ECN No. N/A & \\
\hline Name & & MSIN & $\begin{array}{c}\text { Text } \\
\text { With All } \\
\text { Attach. }\end{array}$ & Text Only & $\begin{array}{l}\text { Attach./ } \\
\text { Appendix } \\
\text { Only }\end{array}$ & $\begin{array}{c}\text { EDT/ECN } \\
\text { Only }\end{array}$ \\
\hline $\begin{array}{l}\text { Central Files } \\
\text { N. R. Brown } \\
\text { K. C. Burgard } \\
\text { R. Carreon } \\
\text { R. L. Gibby } \\
\text { L. A. Huffman } \\
\text { A. A. Kruger } \\
\text { OSTI (2) } \\
\text { J. W. Shade } \\
\text { D. J. Washenfelder }\end{array}$ & $\begin{array}{l}A 3-88 \\
A 3-36\end{array}$ & $\begin{array}{l}\mathrm{L}-04 \\
S 7-53 \\
\mathrm{G} 6-13 \\
S 7-53 \\
H 5-27 \\
S 7-53 \\
H 5-27 \\
\mathrm{~L}-07 \\
H 5-27 \\
H 5-27\end{array}$ & $\begin{array}{l}x \\
X \\
X \\
X \\
X \\
X \\
X \\
X \\
X \\
X\end{array}$ & & & . \\
\hline
\end{tabular}

8 Distaigution of THIS DOCUNENT IS UNLMMTED 


\section{In Situ Monitoring of Grouted Electrolytes}

Prepared for the U.S. Department of Energy Office of Environmental Restoration and Waste Management

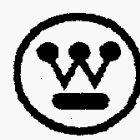
Hanford Company Richland, Washington

Hanford Operations and Engineering Contractor for the

U.S. Department of Energy under Contract DE-AC06-87RL10930

Copyright Libense By acceptance of this article, the publisher and/or recipient acknowledges the

U.S. Govemment's right to retain a nonexclusive, royalty-free license in and to any copyright covering this peper. 


\title{
In Situ Monitoring of Grouted Electrolytes
}

\author{
A. A. Kruger \\ Date Published \\ May 1995
}

To Be Published in

Journal of the Electrochemical Society

Prepared for the U.S. Department of Energy

Office of Environmental Restoration and

Waste Management

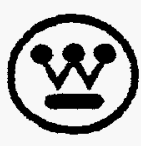

Hanford Operations and Engineering Contractor for the

U.S. Department of Energy under Contract DE-AC06-87RL10930

Copyright Lioenes By acceptance of this article. the publisher and/or recipient acknowiodges the

U.S. Government's right to retain a nonexclusive, royaty-freo license in and to any copyright covering this paper.

\section{If DISTRIBUTION OF thIS DOCLMENT is URUMTEO}


LEGAL DISCLAMER

This report was prepared as an account of work sponsored by an agency of the United States Government. Neither the United States Government nor any agency thereof, nor any of their employees, nor any of their contractors, subcontractors or their employees, makes any warranty, express or implied, or assumes any legal liability or responsibility for the accuracy, completeness, or any third party's use or the results of such use of any information, apparatus, product, or process disclosed, or represents that its use would not infringe privately owned rights. Reference herein to any specific commercial product, process, or service by trade name, trademark, manufacturer, or otherwise, does not necessarily constitute or imply its endorsement, recommendation, or favoring by the United States Government or any agency thereof or its contractors or subcontractors. The views and opinions of authors expressed herein do not necessarily state or reflect those of the United States Government or any agency thereof.

This report has been reproduced from the best available copy.

Printed in the United States of America

DISCLM-2.CHP (1-91) 


\section{DISCLAIMER}

Portions of this document may be illegible in electronic image products. Images are produced from the best available original document. 



\title{
In Situ Monitoring of Grouted Electrolytes
}

\section{G.L.M.K.S. Kahanda, Jingyan Gu and Micha Tomkiewicz Physics Department, Brooklyn College of CUNY, Brooklyn, NY 11210, USA.}

\author{
Albert A. Kruger \\ Westinghouse Hanford Company \\ Richland, WA 99352, USA
}

\begin{abstract}
We describe conductivity measurements of grouts flooded with water and in contact with a sink that consists of pure water. The conductivity measurements were designed and carried out in parallel with present quality verification methods and standard leach test of the nuclear waste management industry. For the first time, we show that the method of replacing intrusive chemical analysis with conductivity measurements of the leaching samples yield equivalent results.
\end{abstract}

\section{Introduction}

Cement-based composites are widely used in applications which demand long term service life. One important example is in immobilization matrices for low-level radioactive[1] and other hazardous wastes, which demands long term retention and durability. Transport of ionic species generally plays a major roll in the utilization, durability and service life of these materiais. For example: corrosion of steel in reinforced concrete[2], sulfate degradation of concrete[3], leaching of hazardous ionic species from repositories[4], is a short list of degredative and non-durable processes associated with cement composites and controlled by the transport of ionic components.

Corrosion of steel in reinforced concrete results in deterioration of the structure, and जc DISTRIBUTION OF THIS DOCUMENT IS UNLIMITED 
depends on the chloride concentration at the bar, which needs to reach a critical level in order for corrosion to proceed. When this stage is reached the service life of the structure is over unless expensive repairs are carried out. Early determination and prediction of corrosion will minimize the repair cost and increase the service life. One way to enhance the service life is to have in-situ monitoring capabilities built into these systems to warn for intrusion of chloride ions.

For the waste repository environment, there is an on going effort [5] to find suitable materials for stabilization and solidification processes for radioactive waste covering low to high level radioactivity. Among those, popular until recently, was to immobilize the low-level waste in cementitious grout and dispose it in concrete vaults. However, increasing concern about possible environmental pollution from hazardous waste repositories of chemical, radioactive and industrial wastes, prompt the waste management industry to consider developing long term monitoring techniques for permanently dispose waste in repositories. Specifically, any long-term disposal system of radioactive waste will require monitoring to warn against structural deterioration and leach of the radioactive or hazardous component into the environment.

During the last two decades, there have been many contributions [6-10] toward developing a standardized test, ANS 16.1 [11], for grout quality evaluation. The evaluation is done by performing in house leach test and obtaining the leachability coefficient [11] of the grouts. As proposed, the same test method can be adapted to monitor the buried radioactive wastes, by physical sampling and carrying out the leach test in the laboratory.

Although, this ex-situ procedure would provide a high level confidence in the data, it also results in generation of secondary waste streams and increased exposure to radiation for workers. Therefore, it is highly desirable that a method be developed for remotely sensing the grout. 
In this communication we describe the application of metal electrodes that will sense the dynamic properties of ions in the grout. The basic unit structure consists of four electrodes through which we perform a resistivity measurement during simulated water flooding and subsequent leaching of ions into the outer environment.

\section{Theoretical Background}

We assume that the dominant transport mode in the grouts is diffusion. The concentration $C(x, t)$ at a point $x$, at time $t$, can be obtained from the solution to the diffusion equation (1);

$$
\frac{\partial C(x, t)}{\partial t}=D \frac{\partial^{2} C(x, t)}{\partial x^{2}}
$$

with the proper boundary conditions. The experimental arrangements and the associated boundary conditions are shown in figure 1. For water diffusion into a dry sample (figure(1a));

(a) $\quad \mathrm{C}(\mathrm{x}, 0)=0$ (for a dry sample)

(b) $\quad \mathrm{C}(0, \mathrm{t})=\mathrm{C}_{\mathrm{wo}_{\mathrm{o}}}$ (Concentration of the water at the entry point)

(C) $\quad \mathrm{C}(\infty, \mathrm{t}) \rightarrow 0$

Solving equation (1) with these boundary conditions for diffusion of pure water into the grout will produce the following concentration profile];

$$
C_{w}(x, t)=C_{w o}\left[1-\operatorname{erf}\left(\frac{x^{*}}{2 \tau^{n}}\right)\right]
$$


Where $\mathrm{x}^{*}=\mathrm{x} / l, \tau=\mathrm{D}_{\text {eff }} \mathrm{t} / l^{2}$ and $l$ is the sample length, $\mathrm{D}_{\text {eff }}=\mathrm{D}_{\mathrm{w}}$ is the effective diffusion coefficient of water in the sample. The value of $n$ reflects the deviation from unrestricted Gaussian type $(n=0.5)$ diffusion.

Similarly one can show that leaching of the electrolyte into a sink of pure water from a wet grout ( figure(1b)) is subject to following boundary conditions;

(d) $\quad \mathrm{C}(\mathrm{x}, 0)=\mathrm{C}_{0}$ (initial concentration of ions)

(e) $\quad \mathrm{C}(0, \mathrm{t})=0$

and will produce the following profile:

$$
C_{n}(x, t)=C_{0} \text { erf }\left(\frac{x^{*}}{2 \tau^{n}}\right)
$$

where $C_{n}(x, t)$ is the concentration of the electrolyte. In equations (2) and (3), erf is stand for the error function.

For sample saturated with the electrolyte the specific conductivity $(\boldsymbol{k})$ is proportional to the equilibrium electrolyte concentration (or activity) $\left(\mathrm{C}_{\mathrm{eq}}\right)$ :

$$
\kappa=\Lambda_{0} C_{e q}
$$

with $\Lambda_{0}=F\left(u_{+}+u_{-}\right)$the equivalent conductivity of the electrolyte and $u_{ \pm}$the ionic mobilities.

In the case of water flow, we will approximate the mobilities in terms of an exponential function that depends on the solvent penetration through: 


$$
\Lambda \approx \Lambda_{0}\left[1-\exp ^{-\alpha C_{w}(x, t)}\right]
$$

Equation (4) can be rewritten as $\kappa_{w}=\Lambda C_{0}$; where $C_{0}$ is the concentration of ions after the percolation of the solvent, assumed here to be the initial concentration of diffusing ions in the leaching stage.

Following percolation of the water experiment, the conductivity will assume the following form:

$$
\kappa_{w}=\Lambda_{0} C_{0}\left[1-\exp ^{-\alpha C_{w}(x, t)}\right]
$$

The measured resistance $(R)$ between the two electrodes is related to the conductivity ( $\kappa$ ) through the separation between the electrodes (x) and the electrode surface area (A) exposed to the electrolyte. By considering two electrodes placed at $x_{1}$ and $x_{2}$, we can write the resistance as:

$$
R=\frac{1}{A} \int_{x_{1}}^{x_{2}} \frac{d x}{\kappa(x, t)}
$$

If we assume the concentration given in the equation (3) is the equilibrium concentration $\left(\mathrm{C}_{\mathrm{eq}}\right)$ of the system, then we can combine equations $(2-7)$ to yield the general expression between the resistance and the total ionic concentration between the two electrodes as follows;

For the case of initial deionized water flooding:

$$
R=\frac{l}{A \Lambda C_{0}} \int_{x_{1}}^{x_{2}} \frac{d x}{1-\exp ^{-\alpha C_{w 0}\left[1-e r f\left(\frac{x}{2 \tau^{n}}\right)\right]}}
$$


and for the case of diffusion of ions out from the electrolyte saturated grout;

$$
R=\frac{l}{\Lambda A C_{0}} \int_{x_{1}}^{x_{2}} \frac{d x}{\operatorname{erf}\left(\frac{x}{2 \tau^{n}}\right)}
$$

An experiment based on ANS. 16.1 [11] method was done during the resistance measurement. In such an experiment, one can analyze the collected leachate as follows: Using equation (3) for the concentration during the leaching experiment, one can obtained the rate of loss of diffusing ions from the electrolyte saturated samples by calculating the flux at the grout-sink interface;

$$
F=D\left[\frac{d C(x, t)}{d x}\right]_{x=0}=\frac{D C_{0}}{\sqrt{\pi D t}}
$$

The total amount $\left(M_{t}\right)$ of the diffusing material that has left the medium at time $t$ can be obtained by integrating equation (10) to yield;

$$
M_{t}=2 C_{0} \sqrt{\frac{D_{e f f} t}{\pi}}
$$

This expression is the same as that used in the ANS. 16.1 method.

\section{Experimental Procedure}

We report here results on the cementitious blend with the flowing composition: Portland Cement Type I/II 20.7 wt\%, Fly Ash Class F 68.3 wt\%, and Attapulgite Clay 11 wt\%. The three powders in the composite were mixed for $48 \mathrm{hrs}$ in a V-shape blender, then mixed with appropriate 
electrolytes $(w / c=1: 1)$ in a mixture for 15 minutes to form a consistent past. Stainless steel wires of $0.0024 "$ diameters were used as electrodes.

Samples for deionized water flooding and leaching experiment were set in a cylindrical (3 $\mathrm{cm}$ diameter and $15 \mathrm{~cm}$ high) Lucite mold and cured at normal room temperature conditions for 28 days. Dry grout samples were carefully cut either into four or two electrode configurations and then fitted into the specially design electrochemical cell [13] with an epoxy coat.

It has been shown $[14,15]$ that impedance of the electrolyte saturated grout, in the frequency range of $10^{-2}$ to $10^{7} \mathrm{~Hz}$, can be represented by a single parallel $\mathrm{RC}$ element. The measurements that we present here are single frequency measurements. An applied $\mathrm{AC}$ voltage $(30 \mathrm{mV}$ at $500 \mathrm{~Hz})$ of the generator was imposed between the outer electrodes and the voltage drop between the inner electrodes was measured. The current flowing through the sample was measured through the voltage drop across a series resistor with a known resistance.

Initiation of the deionized water flooding experiment was carried out with the external deionized water reservoir connected to the inlet of the cell. During the deionized water flow, the time variation of the resistance of the sample is monitored. Once the cell was filled with the deionized water, the external reservoir was disconnected from the cell.

The continuous monitoring of the resistance shows a sudden decrease in resistance as the deionized water enters the sample, followed by an intermediate saturation stage, where the resistance reaches a constant value as the dissolution-precipitation process brings the system into equilibrium. Figure (2) shows the variation of the resistance during the initial water flooding.

As soon as the external reservoir is disconnected, the cell now filled with deionized water, acts as a sink to mark the beginning of the leach test. We have followed the ANS. 16.1 suggested 
leachate renewal steps (except the 2 and 7 hours renewals), and the initial renewal was done at the end of the first day (i. e. 24 hours from the initiation of the test) and continued for the next six days at 24 hour intervals. Additional replacements and collections were done at 14, 28, 56, 84 and 112 days. However, the resistance of the sample was monitored on a daily basis with 24 hours sampling intervals.

The collected leachates were analyzed by applying two procedures: $\mathrm{Na}^{+}$concentration was monitored using Flame Photometry and the ionic conductivities were measured using Cole-Parmer Model $1484-44 \mathrm{pH} /$ conductivity meter. The conductivity measurement of the leachate provides a measure of the overall ionic concentration, while the Flame Photometry allows us to follow the concentration of a single ion.

\section{Discussion}

Figure (2) shows the time variation of the resistance for the initial flooding stage of a sample prepared with ( $1 \mathrm{M} \mathrm{NaOH} / 1 \mathrm{M} \mathrm{NaNO}_{3}$ ) electrolyte together with a fit to equation (8). The effective diffusion coefficient $\left(D_{w}\right)$ obtained from the data fitting is given in table (1) and is in the same order of magnitude as the diffusion coefficient of free water. The value of $n$ is in the range of 0.14 to 0.16 , which suggests that the transport process is not purely diffusional and one must need to incorporate other mechanism such as sorption-desorption and the rate of flow of the flooding water.

An example of the resistance changes during the leach test is shown in figure (3). The figure shows the time variation resistance and the fit of the data to equation (7) of a grout sample prepared with $1 \mathrm{M} \mathrm{NaOH}$ electrolyte. The effective diffusion coefficient obtained through the data fitting is 
given in the table (1). The diffusion coefficients of the electrolytes in the grouts range from $3.35 \mathrm{x}$ $10^{-6} \mathrm{~cm}^{2} / \mathrm{s}$ to $4.03 \times 10^{-6} \mathrm{~cm}^{2} / \mathrm{s}$. These values are one order of magnitude less than the diffusion coefficient of free water. The value of $\mathrm{n}$ falls between 0.51 and 0.56 suggesting that the diffusional process is closer to unrestricted Gaussian.

Once the grout is saturated with water and connected to a sink, there can be two dominating processes responsible for the increase in resistance. One process is due the leaching of ionic species to the outer environment and the other due to further hydration of the cement blend. A simple background experiment in which we monitor the variation of resistance of water saturated sample without a sink was done to distinguish between these two processes. Figure (4) shows the time variation of the resistance of the background experiment and the data from one sample under the leach test. It clearly shows that the hydration is not significant during this period. It can be inferred that the increasing resistance of a sample under a leach test is due to the leaching of ions.

The total amount of ions calculated from the time variation of the concentration of $\mathrm{Na}^{+}$in the leachate obtained by the Flame Photometry is shown in figure (5). Again the data were fit to equation (11) from which the corresponding diffusion coefficients were evaluated and found to be in the range of $2.62 \times 10^{-6} \mathrm{~cm}^{2} / \mathrm{s}$ to $6.16 \times 10^{-6} \mathrm{~cm}^{2} / \mathrm{s}$. Similarly, similar information was extracted from the conductivity data of the electrolyte and given in the table (1).

By using the value of $\mathrm{C}_{0}$ and the term $\left(l / \Lambda \mathrm{AC}_{0}\right)$ in equation (6) or (7), we can calculate the equivalent conductivity $\left(\Lambda_{0}\right)$ of the cement sample made from different electrolytes. For samples made with $1 \mathrm{M} \mathrm{NaOH}$ electrolyte $\Lambda=197.46 \mathrm{~cm}^{2} \Omega^{-1}$ eqvivir and those made with binary electrolyte $1 \mathrm{M} \mathrm{NaOH}+1 \mathrm{MNaNO}_{3}, \Lambda=203.53 \mathrm{~cm}^{2} \Omega^{-1}$ eqviv ${ }^{-1}$. The calculated values for the corresponding free electrolytes are 248.11 and 319.55 respectively. The equivalent conductance of $\mathrm{OH}^{-}$ions is $197 \mathrm{~cm}^{2}$ 
$\Omega^{-1}$ eqviv $v^{-1}$. This is a strong indication that the dominant conductance in the grout is due to $\mathrm{OH}-$ ions, irrespective of the composition of the grout. The ionic conductance of this ion in the grout is approximately the same as in pure solvent.

The agreement between the $e_{\text {Deff }}$ of ions in the grout measured by both method shows that instead of intrusive chemical analysis one can use in-situ resistivity measurement to monitor the overall performances of the grouted electrolyte.

Acknowledgment: This work had been supported by the Hanford Grout Disposal program of the Westinghouse Hanford Company under contract MJL-SVV-097505. We would like to thank Dr. W. M. Shen for his support during the initial phase of this work.

\section{References:}

(1) M. Atkins, F. P. Glasser, " Application of Portland Cement-based Materials to Radioactive Waste Immobilization", Waste Management, 12, 105-131(1992)

(2) R. E. Stratfull, "The Corrosion of Steel in a Reinforced Concrete Bridge Deck", Corrosion, N0.3, 19,44(1957)

(3) F. M. Lea, "The Chemistry of Cement and Concrete" Edward Arnold Ltd., (1990)

(4) R. B. Pojasek, "Toxic and Hazardous Waste Disposal" Ann Arbor Science Pub., Vol.1 (1979)

(5) See for example, "Nuclear Waste Disposal", MRS Bulletin, XIX (12), December (1994)

(6) International Atomic Energy Agency; "Leach testing of immobilized radioactive waste solids, a proposal for a standard method" E.D. Hespe, ed. At. Energy Rev. 9, 195(1971).

(7) J.G. Moore, H.W. Godbee, A.H. Kibbey; Nucl. Tech. 32, 39(1977) 
(8) H.W. Godbee, E.L. Compere, D.S. Joy, A.H. Kibbey, J.G. Moore, C.W. Nestor Jr., O.U. Anders, R.M. Nielsen Jr., Nucl. Chem. Waste Management, 1, 29(1980).

(9) C.W. Nestor Jr., ORNL/CSD/TM-84, Oak Ridge National Laboratory (1980)

(10) R.A.J. Sambell, C. Smitton, A. Elsden; Nucl. Chem. Waste Management, 3, 125(1982).

(11) American Nuclear Society, "Measurement of the Leachability of Solidified Low-Level Radioactive Waste by a Short-Term Procedure: An American National Standard." ANSU/ANS 16.1, 1986 La Grange Park, Illinois.

(12) J. Crank; "The Mathematics of Diffusion", Oxford University Press (1975)

(13) G. L. M. K. S. Kahanda, A. A. Kruger, J. Gu, W.M. Shen, M. Tomkiewicz; "Scientific basis for nuclear waste management XVII", Mat. Res. Soc. Symp. Proc. 333, pp 357-362(1994)

(14) A. A. Kruger, J. Gu, M. Tomkiewicz; " Scientific basis for Nuclear waste management XVI", Mat. Res. Soc. Symp. Proc. 294, pp 291-296(1993).

(15) J. Gu, W.M. Shen, M. Tomkiewicz, A.A. Kruger; Proceedings of the International Conference on Nuclear Waste Management and Environmental Remediation, 3, 599(1993) 


\section{Figure Caption:}

Figure (1): The experimental arrangement of the electrochemical cell and the associated boundary conditions, (a) for water diffusion in and (b) leaching of ions out of the sample.

Figure(2): Time variation of the resistance during the initial water flooding of a sample prepared with $1 \mathrm{M} \mathrm{NaOH} / 1 \mathrm{M} \mathrm{NaNO}_{3}$ electrolyte and the fit to equation (8).

Figure(3): Time variation of the resistance during the leach rest. Sample prepared with $1 \mathrm{M}$ $\mathrm{NaOH}$ electrolyte.

Figure(4): The time variation of the resistance of the background experiment (see text) and the resistance data from one sample under leach test.

Figure(5): Ionic concentration of leached ions calculated from flame photometric measurements of $\mathrm{Na}^{+}$in the leachate. 
Table 1

\begin{tabular}{|c|c|c|c|c|c|c|c|c|}
\hline \multirow{3}{*}{ Sample ID } & \multicolumn{2}{|c|}{$\begin{array}{c}\text { During Water } \\
\text { Flooding }\end{array}$} & \multicolumn{2}{c|}{$\begin{array}{c}\text { During Ionic } \\
\text { Diffusion }\end{array}$} & \multicolumn{2}{|c|}{$\begin{array}{c}\text { Flame Photometry } \\
\text { Measurement }\end{array}$} & \multicolumn{2}{c|}{$\begin{array}{c}\text { Conductivity } \\
\text { Measurement }\end{array}$} \\
\cline { 2 - 9 } & $\begin{array}{c}\mathrm{D}_{\mathrm{w}} \\
\mathrm{cm}^{2} / \mathrm{s}\end{array}$ & $\mathrm{n}$ & $\begin{array}{c}\mathrm{D}_{\text {eff }} \\
\mathrm{cm}^{2} / \mathrm{s}\end{array}$ & $\mathrm{n}$ & $\begin{array}{c}\mathrm{D}_{\text {eff }} \\
\mathrm{cm}^{2} / \mathrm{s}\end{array}$ & $\begin{array}{c}\mathrm{C}_{\mathrm{o}} \\
\mathrm{mole} / \mathrm{cm}^{3}\end{array}$ & $\begin{array}{c}\mathrm{D}_{\text {eff }} \\
\mathrm{cm}^{2} / \mathrm{s}\end{array}$ & $\begin{array}{c}\mathrm{C}_{\mathrm{o}} \\
\mathrm{mole} / \mathrm{cm}^{3}\end{array}$ \\
\hline $\mathrm{A}: \mathrm{NaOH}$ & $8.73 \times 10^{-5}$ & 0.16 & $4.03 \times 10^{-6}$ & 0.51 & $2.62 \times 10^{-6}$ & $2.75 \times 10^{-4}$ & $2.42 \times 10^{-6}$ & $2.24 \times 10^{-4}$ \\
\hline $\mathrm{B}: \mathrm{NaOH}$ & $8.43 \times 10^{-5}$ & 0.14 & $3.35 \times 10^{-6}$ & 0.52 & $2.94 \times 10^{-6}$ & $2.23 \times 10^{-4}$ & $2.84 \times 10^{-6}$ & $2.02 \times 10^{-4}$ \\
\hline $\mathrm{A}: \mathrm{NaOH} / \mathrm{NaNO}_{3}$ & $8.48 \times 10^{-5}$ & 0.15 & $6.23 \times 10^{-6}$ & 0.54 & $6.16 \times 10^{-6}$ & $4.95 \times 10^{-4}$ & $4.01 \times 10^{-5}$ & $2.84 \times 10^{-4}$ \\
\hline $\mathrm{B}: \mathrm{NaOH} / \mathrm{NaNO}_{3}$ & $8.44 \times 10^{-5}$ & 0.16 & $5.32 \times 10^{-6}$ & 0.56 & $5.76 \times 10^{-6}$ & $4.50 \times 10^{-4}$ & $3.84 \times 10^{-6}$ & $2.74 \times 10^{-4}$ \\
\hline
\end{tabular}




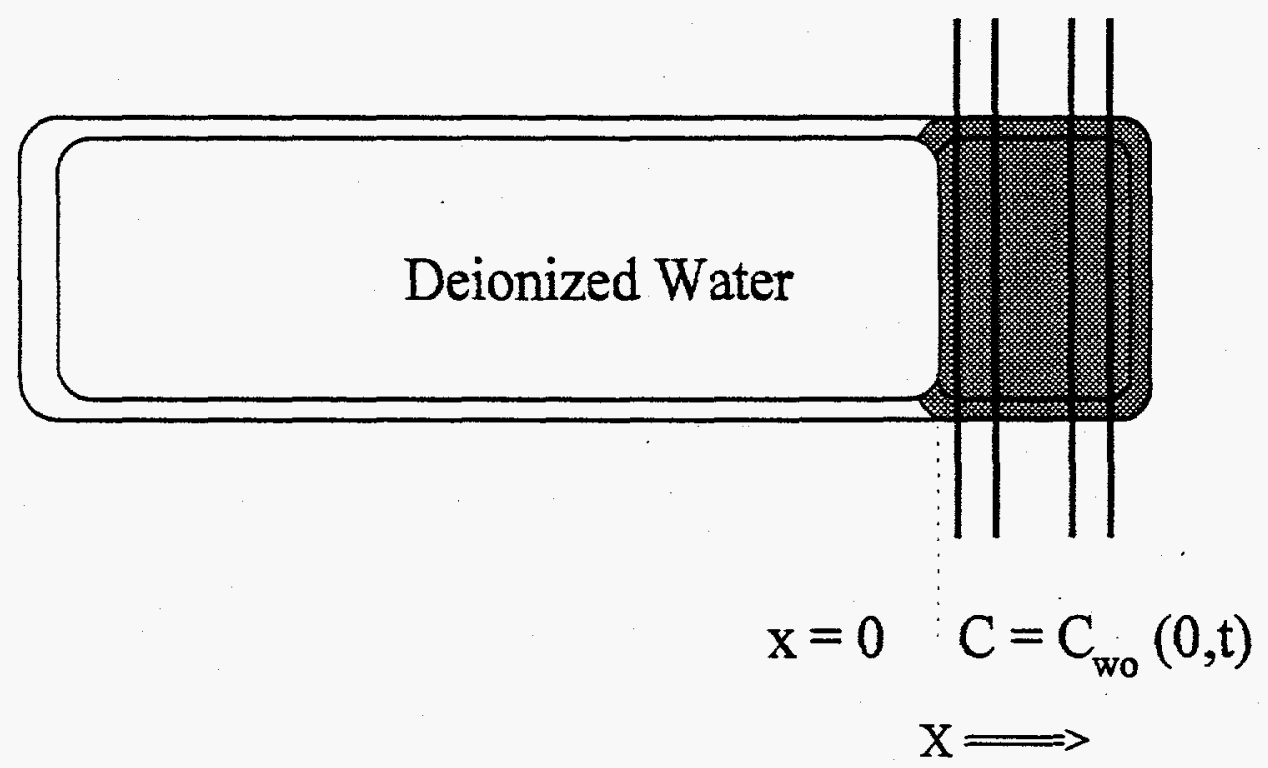

(a)

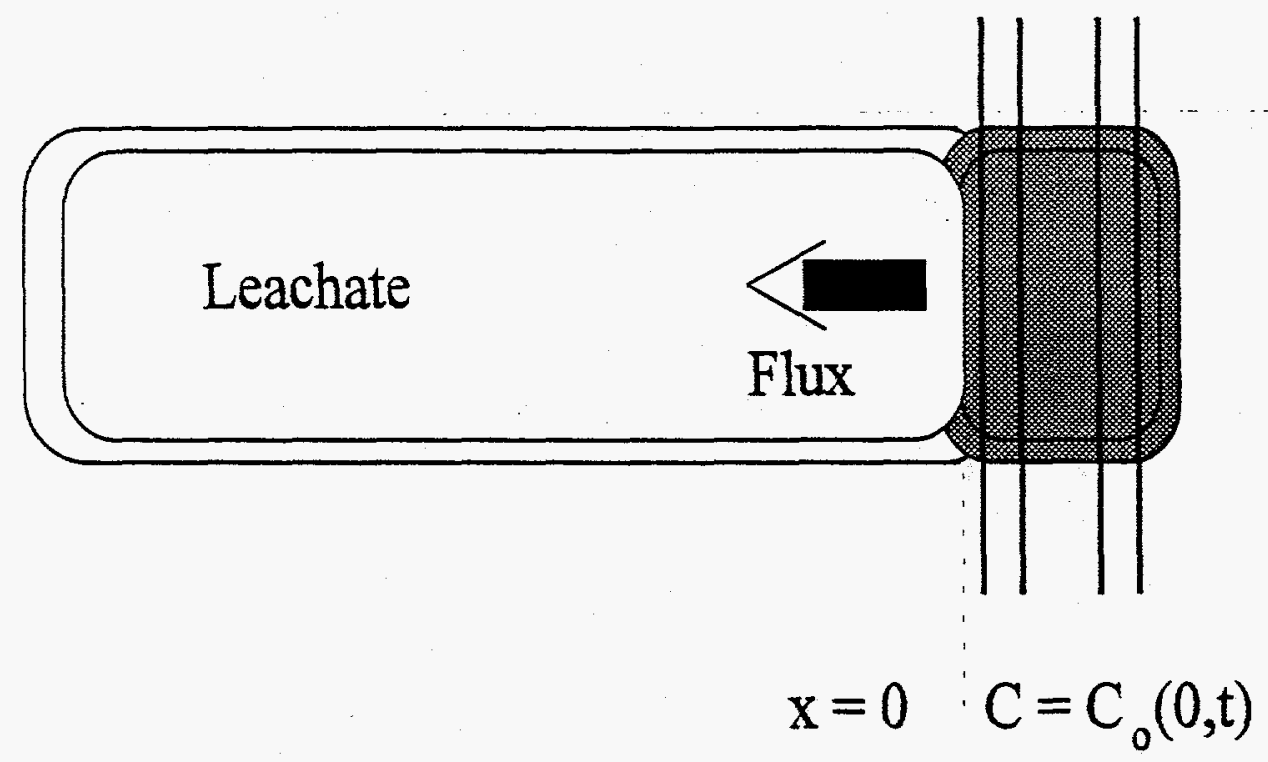

(b)

Figure (1) 


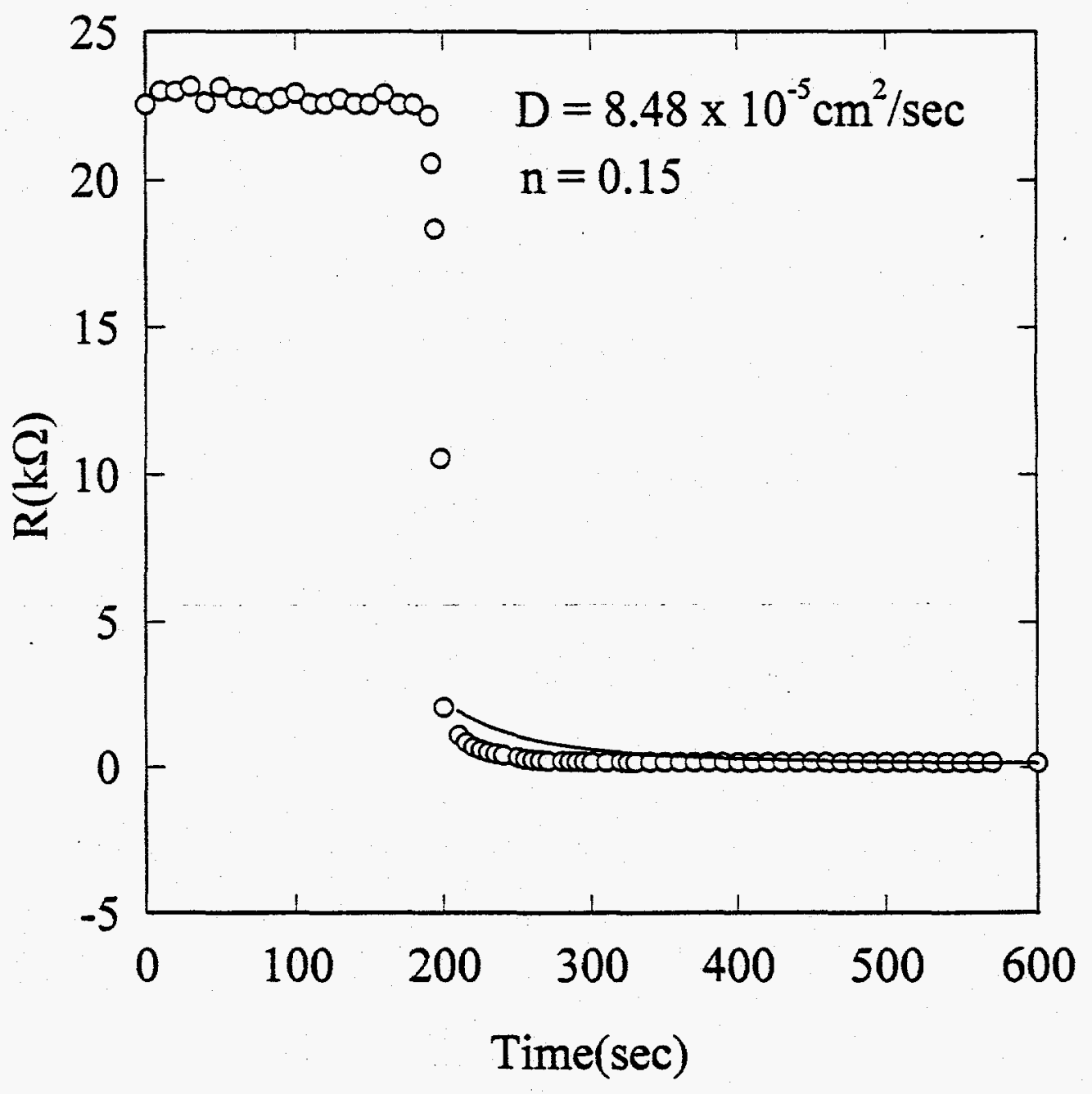

Figure (2) 


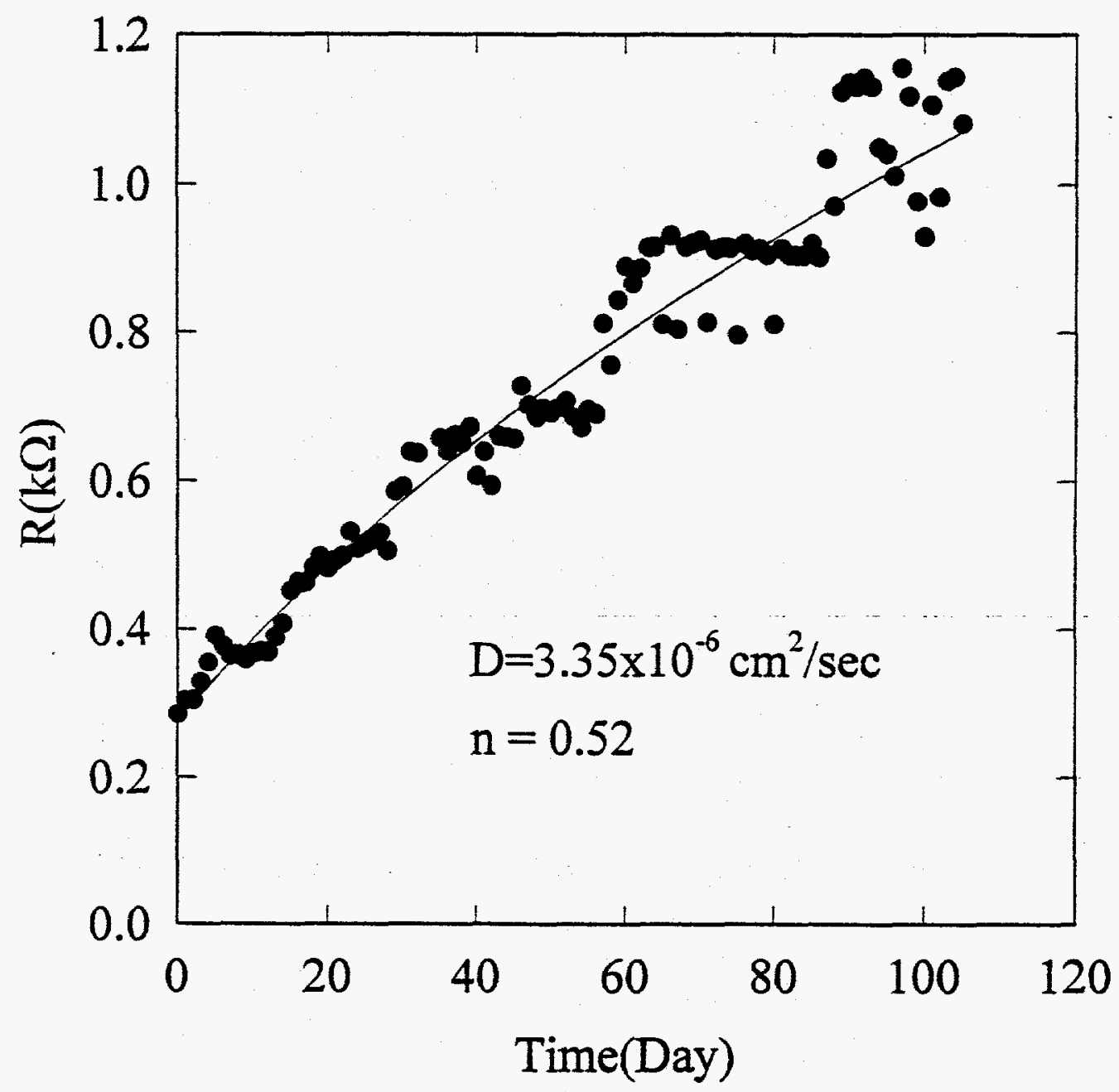

Figure (3) 


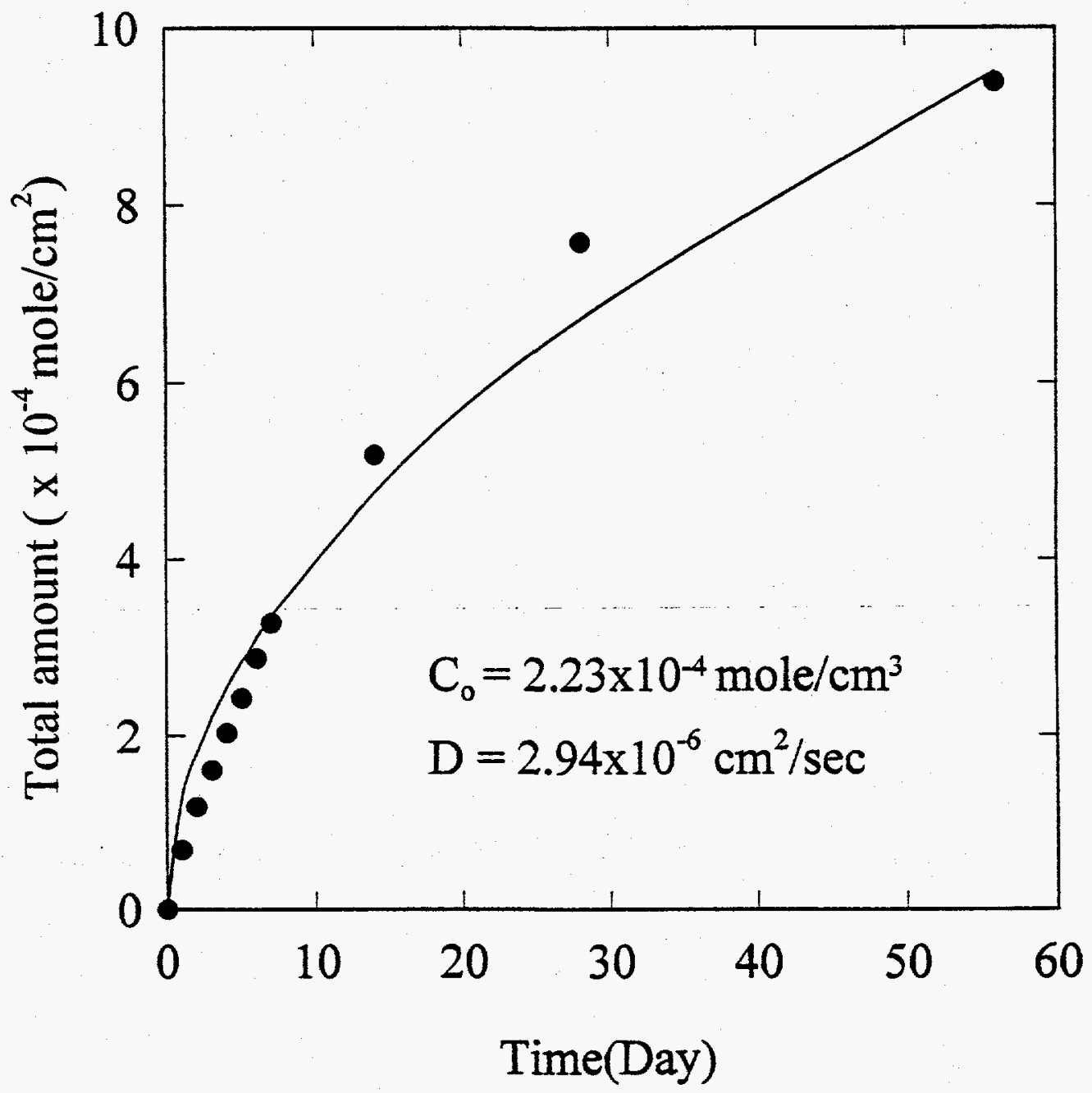

Figure (5) 